CZASOPISMO INŻYNIERII LĄDOWEJ, ŚRODOWISKA I ARCHITEKTURY JOURNAL OF CIVIL ENGINEERING, ENVIRONMENT AND ARCHITECTURE

JCEEA, t. XXXIII, z. 63 (4/16), październik-grudzień 2016, s. 477-488

\author{
Elżbieta RYBAK-WILUSZ ${ }^{1}$ \\ Klaudia HOPP ${ }^{2}$
}

\title{
ANALIZA ENERGETYCZNO-EKONOMICZNA WYKORZYSTANIA ENERGII SŁONECZNEJ
}

\begin{abstract}
Celem analizy energetyczno-ekonomicznej jest ocena efektywności wykorzystania energii słonecznej do ogrzewania ciepłej wody w instalacji z kolektorami cieczowymi. Polega ona, między innymi, na wyznaczaniu energii promieniowania słonecznego docierającego do powierzchni kolektora o określonej lokalizacji i pochyleniu oraz zapotrzebowania na ciepło. W dłuższych okresach czasu (miesiąc, rok) potrzeby cieplne do ogrzewania ciepłej wody użytkowej są stałe, w odróżnieniu od zmiennego promieniowania słonecznego. Powoduje to pewną trudność w oszacowaniu efektów działania instalacji słonecznej, z uwagi na szereg parametrów określających pozycją Słońca pozwalających na wyznaczenie składowych promieniowania słonecznego. W artykule wykonano ocenę energetyczną działania instalacji ciepłej wody w budynku mieszkalnym z wykorzystaniem metody f-chart. Metoda ta pozwala na ocenę efektów działania instalacji na podstawie ogólnej charakterystyki kolektorów słonecznych i uśrednionych danych meteorologicznych. Wykonano analizę porównawczą dwóch instalacji, z kolektorami cieczowymi płaskimi i próżniowymi. Wyznaczono dla okresów miesięcznych, na podstawie oszacowanego udziału energii słonecznej w pokryciu potrzeb cieplnych podgrzania wody, średnią sprawności instalacji. W tym celu wykorzystano korelacje pomiędzy dwoma bezwymiarowymi zmiennymi $X$ i $Y$.

Analiza ekonomiczna instalacji słonecznej, po uwzględnieniu kosztów inwestycyjnych i eksploatacyjnych, daje pełny obraz oszczędności z tytułu wykorzystania promieniowania słonecznego. Wnioski z analizy wskazują czynniki, które mogą być brane pod uwagę przy wyborze rodzaju kolektorów słonecznych oraz w praktycznych rozwiązaniach instalacji słonecznych charakteryzujących się wysoką sprawnością cieplną.
\end{abstract}

Słowa kluczowe: metoda f-chart, kolektor płaski cieczowy, kolektor próżniowy instalacja ciepłej wody, efektywność energetyczna, wskaźniki finansowe

\footnotetext{
${ }^{1}$ Autor do korespondencji / corresponding author: Elżbieta Rybak-Wilusz, Politechnika Rzeszowska, Zakład Ciepłownictwa i Klimatyzacji, ul. Powstańców Warszawy 6, $35-959$ Rzeszów; tel. 178651445; e-mail: elrywi@prz.edu.pl

${ }^{2}$ Klaudia Hopp, Politechnika Rzeszowska ; tel. 886722476; e-mail: klaudia_h@interia.eu
} 


\section{Wprowadzenie}

Popularność wykorzystania energii słonecznej do przygotowania ciepłej wody w gospodarstwach domowych, w przeciwieństwie od innych odnawialnych źródeł energii, takich jak na przykład biomasa stała, spowodowana jest potrzebą jej magazynowania tylko w krótkim okresie czasu. Wytworzone ciepło możne być przetrzymywane w zbiornikach ciepłej wody przez 2 lub 3 doby, w zależności od konstrukcji zasobnika. W obiektach o dużym zużyciu ciepła niskotemperaturowego, którymi są instalacje ciepłej wody użytkowej istnieją możliwości zastosowania zintegrowanych systemów zaopatrzenia w energię [1]. Umożliwiają one wykorzystanie odnawialnych nośników ciepła takich jak promieniowanie słoneczne, ciepło gruntu i dają sposobność skojarzonej produkcji ciepła i energii elektrycznej. Sprzyjają w ten sposób rozwojowi energetyki rozproszonej ograniczając inwestycje sieciowe [1]. Innym argumentem, który przemawia za wykorzystaniem energii słonecznej jest brak emitowania jakichkolwiek zanieczyszczeń do atmosfery oraz ciągła zdolność do odbudowy zasobu energetycznego, w stosunkowo krótkim okresie czasu, zależnie od występujących na danym obszarze warunków klimatycznych.

Obecnie stosowanych jest kilka rodzajów instalacji słonecznych, wykorzystujących różne urządzenia do konwersji promieniowania słonecznego w ciepło. Szereg kombinacji i wariantów instalacji niesie za sobą szeroki zakres możliwości ich wykorzystania. Nie można jednoznacznie wskazać jednego, najlepszego rozwiązania. Zasadność stosowania danego rodzaju instalacji zależy w szczególności od specyfiki zapotrzebowania na ciepłą wodę oraz warunków klimatycznych panujących na danym terenie.

Celem badań jest rozpoznanie zagadnienia efektywności energetycznej wykorzystania energii słonecznej w ogrzewaniu ciepłej wody na podstawie analizy energetyczno-ekonomicznej instalacji słonecznej wyposażonej w kolektory cieczowe płaskie i próżniowe. W wyznaczeniu wskaźników technicznych wykorzystano metodę f-chart, natomiast $\mathrm{w}$ analizie opłacalności inwestycji zastosowano statyczne i dynamiczne wskaźniki finansowe.

\section{Założenia do obliczeń}

Ocena działania instalacji solarnej, w tym obliczenia procentowych udziałów energii słonecznej i energii pochodzącej ze źródła konwencjonalnego wykorzystanej do podgrzewania wody użytkowej, dokonana została za pomocą metody f-chart, przeznaczonej głównie dla kolektorów cieczowych. Metoda ta jest prezentowana $\mathrm{w}$ wielu publikacjach z tego zakresu [2],[3],[4]. Umożliwia określenie w jakim stopniu energia słoneczna będzie wspomagać instalacje ciepłej wody, pozwala wyznaczyć sprawności instalacji kolektorowej oraz oszczędności z tytułu wykorzystania energii słonecznej. 
Obliczenia w metodzie f-chart można podzielić na obliczenia pomocnicze oraz obliczenia główne. Podstawową cechą metody jest wykorzystanie korelacji pomiędzy dwoma bezwymiarowymi zmiennymi $X$ (wzór 1) i $Y$ (wzór 2) wynikającymi z parametrów konstrukcyjnych i eksploatacyjnych instalacji. Na ich podstawie określa się funkcje korelacyjną $f$ (wzór 3), która wyznacza udział energii promieniowania słonecznego w całkowitym zapotrzebowaniu na c.w.u. dla budynku [5]:

$$
\begin{aligned}
& X=\psi_{x} \frac{86400 \cdot A_{a} \cdot F r U l \cdot\left(11,6+1,18 T_{c}+3,86 T_{z}-2,23 T_{o}\right)}{q_{s} r d \cdot \rho \cdot c_{W} \cdot\left(T_{c}-T_{z}\right)} \\
& Y=\frac{A_{a} \cdot F r(\tau \alpha) \cdot I_{c \beta}}{q_{s r d} \cdot \rho \cdot c_{W} \cdot\left(T_{c}-T_{z}\right) \cdot N} \\
& f=1,029 Y-0,065 X-0,245 Y^{2}+0,0018 X^{2}+0,0215 Y^{3}
\end{aligned}
$$

gdzie: $\psi_{x}$ - współczynnik uwzględniający pojemność zbiornika magazynującego, przyjęto $V s=400 \mathrm{dm}^{3}, A_{a}$ - powierzchnia czynna kolektorów słonecznych, [m²], FrUl - iloczyn współczynnika odprowadzenia ciepła z kolektora i zastępczego współczynnik strat ciepła, $\left[\mathrm{kW} / \mathrm{m}^{2} \cdot \mathrm{K}\right], \operatorname{Fr}(\tau \alpha)$ - średnia miesięczna wartość iloczynu współczynnika odprowadzenia ciepła z kolektora i współczynnika transmisyjnoabsorpcyjnego $(\tau \alpha)$, [-]. Przyjęto dla kolektora płaskiego $F r U l=4,71 \mathrm{~W} /\left(\mathrm{m}^{2} \mathrm{~K}\right)$, $F r(\tau \alpha)=0,8$ [6], [7], a dla kolektora próżniowego $F r U l=2,1 \mathrm{~W} /\left(\mathrm{m}^{2} \mathrm{~K}\right)$, $\operatorname{Fr}(\tau \alpha)=0,617, I_{c \beta}$ - nasłonecznienie całkowite na powierzchnię pochyloną pod kątem $\beta$ dla analizowanego okresu czasu i lokalizacji, $\left[\mathrm{kJ} /\left(\mathrm{m}^{2}\right)\right], T_{c}, T_{z}$ - temperatura ciepłej i zimnej wody, $\left[{ }^{\circ} \mathrm{C}\right], T_{o}$ - temperatura otoczenia, $\left[{ }^{\circ} \mathrm{C}\right], q_{s}$ srd - średnie dobowe zużycie c.w., $\left[\mathrm{dm}^{3} / \mathrm{doba}\right], \rho$ - gęstość wody, $\left[\mathrm{kg} / \mathrm{dm}^{3}\right], c_{w}$ - ciepło właściwe wody, [kJ/(kg.K)], $N$ - liczba dób w miesiącu, [d/mies.].

Przyjęto do analizy instalację w budynku jednorodzinnym usytuowanym w Rzeszowie (szerokość geograficzna $\varnothing=50^{\circ}$ ) zamieszkałym przez 4 osobową rodzinę. Dobowe zużycie ciepłej wody na osobę przyjęto $q_{j}=80 \mathrm{dm}^{3} /$ (os. d). Temperatura zimnej wody wynosi $T_{z}=10^{\circ} \mathrm{C}$ zimą i $15^{\circ} \mathrm{C}$ latem, zaś ciepłej wody $T_{c}=50^{\circ} \mathrm{C}$.

Dokonano porównania dwóch instalacji pod względem efektywności cieplnej. Instalacja słoneczna wyposażona będzie w wariancie pierwszym w 3 płaskie kolektory cieczowe firmy ENSOL typu ES1V/2 o łącznej powierzchni $5,6 \mathrm{~m}^{2}$ i sprawności optycznej $\eta_{0}=80 \%$ oraz $\mathrm{w}$ wariancie drugim 3 kolektory próżniowe firmy HARTMANN typu HS-CS22 o łącznej powierzchni 5,4 $\mathrm{m}^{2}$ i sprawności optycznej $\eta_{0}=61,7 \%$. Kolektory zostały połączone szeregowo, położone pod kątem $\beta=45^{\circ}$ względem horyzontu i skierowane na południe. Czynnikiem roboczym $w$ instalacji będzie płyn solarny stanowiący wodny roztwór glikolu propylenowego. 


\section{Obliczenia efektywności instalacji słonecznej z wykorzystaniem metody f-chart}

Gęstość strumienia energii słonecznej docierającą na powierzchnię poziomą $I_{c}$ obliczamy ze wzoru:

$$
I_{c}=I_{b} \cdot R_{b}+I_{r} \cdot R_{r}, \quad\left[\mathrm{~W} / \mathrm{m}^{2}\right]
$$

gdzie: $I_{b}, I_{r}$ - gęstość strumienia promieniowania bezpośredniego/dyfuzyjnego, [W/m²], $R_{b}, R_{r}$ - współczynnik korelacyjny promieniowania bezpośredniego i dyfuzyjnego. Promieniowanie całkowite wyznaczono uwzględniając pochylenie powierzchni kolektora pod kątem $\beta$ do horyzontu [5].

Pełny tok obliczeń przytoczony w literaturze [2],[3],[4] polega na wyznaczeniu wartości kąta godzinowego $\omega_{w s c h}$ dla znanej szerokość geograficzna $\varnothing\left[^{\circ}\right]$ i deklinacji $\delta\left[^{\circ}\right]$. Obliczono (tab. 1) gęstość strumienia promieniowania słonecznego $I_{z}$ dla wybranego dnia w roku $N_{d}$ docierającego do Ziemi (na orbicie ziemskiej atmosfery), dla stałej słonecznej wynoszącej $G_{s c}=1367 \mathrm{~W} / \mathrm{m}^{2}$; oraz całkowite nasłonecznie na zewnątrz atmosfery dla określonego miejsca w $n$-tym dniu roku $H_{o}$ (tab. 2).

Ilość energii do wytwarzania c.w. w miesiącu, wykorzystanej z promieniowania słonecznego $Q_{\text {stońca }}$ oraz z konwencjonalnego źródła energii $Q_{k o n w}$, obliczamy ze wzoru:

$$
\begin{aligned}
& Q_{\text {stońca }}=f \cdot N \cdot q_{\text {srd }} \cdot \rho \cdot c_{w} \cdot\left(T_{c}-T_{z}\right) \quad[\mathrm{MJ} / \mathrm{mies} .] \\
& Q_{\text {konw }}=(1-f) \cdot N \cdot q_{\text {srd }} \cdot \rho \cdot c_{w} \cdot\left(T_{c}-T_{z}\right)[\mathrm{MJ} / \mathrm{mies} .]
\end{aligned}
$$

Średnia miesięczna sprawność instalacji słonecznej $\eta$ :

$$
\eta=\frac{f \cdot N \cdot q_{s r d} \cdot \rho \cdot c_{w} \cdot\left(T_{c}-T_{Z}\right)}{A_{a} \cdot I_{c \beta}}[-]
$$

\section{Wyniki i analiza obliczeń}

Wyniki obliczeń dla instalacji wyposażonej w kolektory płaskie i próżniowe przedstawiono $\mathrm{w}$ tab. 1,2 i 3.

Analizując wyniki obliczeń (tab.3, rys.1) można stwierdzić, że sprawność instalacji z kolektorami próżniowymi wykazuje mniejszą zmienność w ciągu roku niż sprawność instalacji z kolektorami płaskimi. Kolektory płaskie przyjęte do analizy cechuje wyższa sprawność optyczna w porównaniu z kolektorami próżniowymi, dlatego w okresie lata (IV-IX) instalacje z tymi kolektorami mają wyższe sprawności latem niż instalacje z kolektorami próżniowymi. Średnia sprawność analizowanej instalacji z kolektorami płaskimi w okresie letnim wy- 
niosła $45 \%$, a z kolektorami próżniowymi $43 \%$. Sytuacja jest odwrotna w miesiącach o niższym nasłonecznieniu (I-III, X-XII), wówczas to średnia sprawność instalacji z kolektorami próżniowymi wyniosła 39\% i jest o 5\% wyższa od sprawności instalacji z kolektorami płaskimi. Ma to związek między innymi $\mathrm{z}$ tym, że kolektory próżniowe rurowe lepiej absorbują promieniowanie rozproszone, którego zimą jest więcej niż latem oraz cechują je niższe straty ciepła do otoczenia [5].

Tabela 1. Wyniki obliczeń danych meteorologicznych metodą f-chart

Table 1. Results calculations of meteorological data using the f-chart method

\begin{tabular}{|c|c|c|c|c|c|c|}
\hline \multirow{2}{*}{ Miesiąc } & $\boldsymbol{I}_{\boldsymbol{c}}[12]$ & $\boldsymbol{I}_{\boldsymbol{c}}$ & $\boldsymbol{T}_{\boldsymbol{o}}[13]$ & $\boldsymbol{N}_{\boldsymbol{d}}$ & $\delta$ & $\boldsymbol{I}_{\boldsymbol{z}}$ \\
\cline { 2 - 7 } & {$\left[\mathrm{kWh} / \mathrm{m}^{2} \cdot \mathrm{mies}.\right]$} & {$\left[\mathrm{kJ} / \mathrm{m}^{2} \cdot \mathrm{d}\right]$} & {$\left[{ }^{\circ} \mathrm{C}\right]$} & {$[\mathrm{doba}]$} & {$\left[{ }^{\circ}\right]$} & {$\left[\mathrm{W} / \mathrm{m}^{2}\right]$} \\
\hline I & 31,07 & 3608 & $-2,3$ & 17,00 & $-20,60$ & 1410,19 \\
\hline II & 41,85 & 5381 & $-1,3$ & 47,00 & $-12,53$ & 1398,13 \\
\hline III & 74,46 & 8647 & 2,8 & 75,00 & $-2,05$ & 1379,46 \\
\hline IV & 109,83 & 13180 & 8,5 & 105,00 & 9,74 & 1356,42 \\
\hline V & 150,23 & 17446 & 14,0 & 133,15 & 135,00 & 1336,15 \\
\hline VI & 163,37 & 19604 & 16,8 & 159,78 & 162,00 & 1324,67 \\
\hline VII & 149,87 & 17404 & 18,8 & 195,29 & 198,00 & 1323,49 \\
\hline VIII & 134,34 & 15601 & 18,1 & 224,88 & 228,00 & 1335,03 \\
\hline IX & 84,78 & 10174 & 13,5 & 254,47 & 258,00 & 1354,92 \\
\hline X & 55,84 & 6485 & 8,6 & 284,05 & 288,00 & 1377,96 \\
\hline XI & 30,19 & 3623 & 3,4 & 313,64 & 318,00 & 1398,13 \\
\hline XII & 25,50 & 2961 & $-1,0$ & 339,29 & 344,00 & 1409,20 \\
\hline
\end{tabular}

Tabela 2. Wyniki obliczeń metodą f-chart danych pomocniczych

Table 2. Results calculations of auxiliary data using the f-chart method

\begin{tabular}{|c|c|c|c|c|c|c|}
\hline \multirow{2}{*}{ Miesiąc } & $\boldsymbol{\omega}_{\boldsymbol{w s c h}}$ & $\boldsymbol{H}_{\boldsymbol{0}}$ & $\boldsymbol{I}_{\boldsymbol{r}}$ & $\boldsymbol{I}_{\boldsymbol{b}}$ & $\boldsymbol{R}_{\boldsymbol{b}}$ & $\boldsymbol{I}_{\boldsymbol{c} \boldsymbol{\beta}}$ \\
\cline { 2 - 7 } & {$\left[{ }^{\circ}\right]$} & {$\left[\mathrm{kJ} / \mathrm{m}^{2}\right]$} & {$\left[\mathrm{kJ} / \mathrm{m}^{2} \cdot \mathrm{d}\right]$} & {$\left[\mathrm{kJ} / \mathrm{m}^{2} \cdot \mathrm{d}\right]$} & {$[-]$} & {$\left[\mathrm{kJ} / \mathrm{m}^{2} \cdot \mathrm{d}\right]$} \\
\hline I & 63,38 & 9306,7 & 2075 & 1536 & 3,334 & 6894 \\
\hline II & 74,65 & 14955,3 & 3256 & 2128 & 2,349 & 7780 \\
\hline III & 87,56 & 22774,1 & 5050 & 3604 & 1,650 & 10260 \\
\hline IV & 101,80 & 31731,8 & 7183 & 5986 & 1,198 & 13305 \\
\hline V & 114,25 & 38659,3 & 8828 & 8608 & 0,980 & 15974 \\
\hline VI & 120,47 & 41556,2 & 9469 & 10146 & 0,905 & 17268 \\
\hline VII & 117,28 & 39905,9 & 9085 & 8314 & 0,941 & 15582 \\
\hline VIII & 107,14 & 34527,2 & 7879 & 7728 & 1,091 & 15159 \\
\hline IX & 93,99 & 26596,1 & 5901 & 4285 & 1,408 & 11073 \\
\hline X & 79,77 & 17764,0 & 3891 & 2593 & 2,031 & 8589 \\
\hline XI & 66,68 & 10742,3 & 2286 & 1334 & 2,995 & 5948 \\
\hline XII & 59,84 & 7810,2 & 1732 & 1228 & 3,764 & 6101 \\
\hline
\end{tabular}


Tabela 3. Wyniki obliczeń metodą f-chart efektywności instalacji z kolektorami płaskimi i próżniowymi

Table 3. Results calculations using the f-chart method of the system efficiency with flat-plate and evacuated tube collectors

\begin{tabular}{|c|c|c|c|c|c|c|c|c|}
\hline \multirow{2}{*}{ Miesiąc } & $\boldsymbol{X}$ & $\boldsymbol{Y}$ & $\boldsymbol{f}$ & $\boldsymbol{\eta}$ & $\boldsymbol{X}$ & $\boldsymbol{Y}$ & $\boldsymbol{f}$ & $\boldsymbol{\eta}$ \\
\cline { 2 - 9 } & \multicolumn{3}{|c|}{ Kolektory płaskie } & \multicolumn{3}{c|}{ Kolektory próżniowe } \\
\hline I & 5,687 & 0,614 & 0,233 & 0,303 & 2,398 & 0,457 & 0,275 & 0,371 \\
\hline II & 5,584 & 0,693 & 0,296 & 0,342 & 2,355 & 0,516 & 0,325 & 0,389 \\
\hline III & 5,165 & 0,914 & 0,465 & 0,407 & 2,178 & 0,680 & 0,460 & 0,417 \\
\hline IV & 4,582 & 1,185 & 0,651 & 0,439 & 1,932 & 0,882 & 0,613 & 0,429 \\
\hline V & 4,019 & 1,423 & 0,798 & 0,449 & 1,695 & 1,059 & 0,735 & 0,428 \\
\hline VI & 3,733 & 1,539 & 0,864 & 0,449 & 1,574 & 1,144 & 0,791 & 0,427 \\
\hline VII & 3,528 & 1,388 & 0,807 & 0,465 & 1,488 & 1,033 & 0,732 & 0,437 \\
\hline VIII & 3,600 & 1,351 & 0,785 & 0,465 & 1,518 & 1,005 & 0,714 & 0,439 \\
\hline IX & 4,071 & 0,987 & 0,563 & 0,457 & 1,717 & 0,734 & 0,525 & 0,441 \\
\hline X & 4,572 & 0,765 & 0,394 & 0,412 & 1,928 & 0,569 & 0,392 & 0,425 \\
\hline XI & 5,104 & 0,530 & 0,195 & 0,294 & 2,152 & 0,394 & 0,237 & 0,371 \\
\hline XII & 5,554 & 0,544 & 0,185 & 0,272 & 2,342 & 0,404 & 0,235 & 0,359 \\
\hline
\end{tabular}

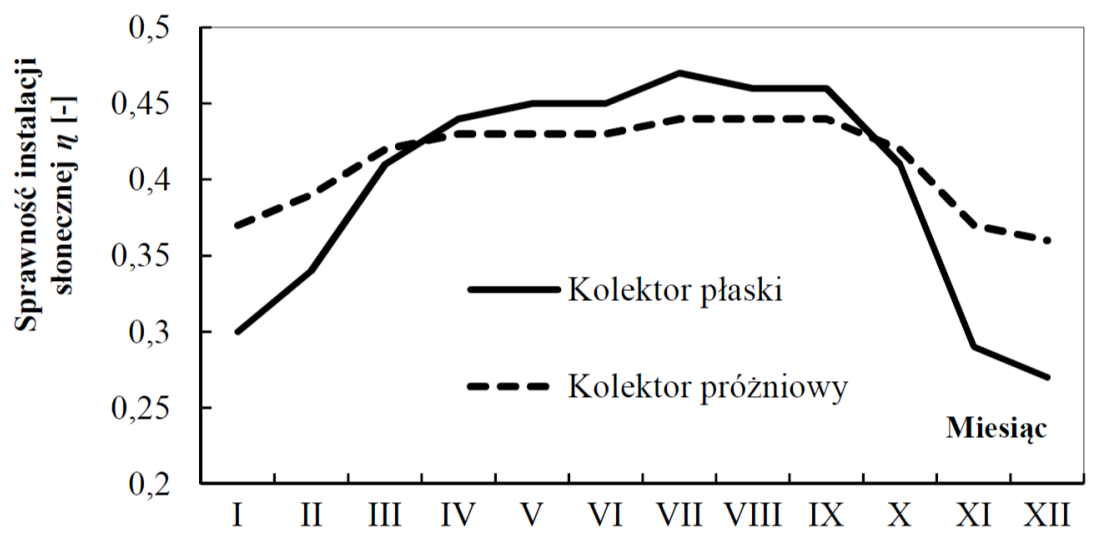

Rys. 1. Średnia miesięczna sprawność instalacji

Fig. 1. Monthly mean installation efficiency

W styczniu, lutym oraz listopadzie i grudniu kolektory próżniowe dostarczą łącznie o około $70 \mathrm{kWh}$ energii więcej niż kolektory płaskie. W marcu i październiku oba kolektory wykazują zbliżone wydajności, natomiast w miesiącach letnich (od kwietnia do września) kolektory płaskie dostarczą łącznie o około $150 \mathrm{kWh}$ energii więcej niż kolektory próżniowe. Im więcej energii instalacja pozyska ze Słońca tym mniej energii dostarczy źródło konwencjonalne, spowoduje to obniżenie kosztów wytwarzania c.w.u. w budynku. 
Tabela. 4. Procentowe pokrycie zapotrzebowania na ciepło przez kolektory płaskie i próżniowe

Table 4. Percentage of heat demand provided by flat-plate and evacuated tube collectors

\begin{tabular}{|c|c|c|c|c|c|c|c|c|c|c|c|c|}
\hline Miesiąc & I & II & III & IV & V & VI & VII & VIII & IX & X & XI & XII \\
\hline Płaski [\%] & 23,3 & 29,6 & 46,5 & 65,1 & 79,8 & 86,4 & 80,7 & 78,5 & 56,3 & 39,4 & 19,5 & 18,5 \\
\hline Próżniowy [\%] & 27,5 & 32,5 & 46,0 & 61,3 & 73,5 & 79,1 & 73,2 & 71,4 & 52,5 & 39,2 & 23,7 & 23,5 \\
\hline
\end{tabular}

Instalacje w obu przypadkach są w stanie, w ciągu roku, pokryć ok. 50\% zapotrzebowania na ciepło do ogrzania wody. W okresie zimowym instalacja z kolektorami płaskimi pokrywa średnio $29,5 \%$ zapotrzebowania na ciepło do ogrzania wody, a z kolektorami próżniowymi $32 \%$, natomiast w okresie letnim wynosi ono: kolektory płaskie 74,5\%, a kolektory próżniowe $68,5 \%$ (tab. 4).

Analizując ilość energii słonecznej do podgrzewania wody uzyskaną w kolejnych miesiącach w ciągu roku (rys. 2) widać, że dla obu instalacji słonecznych największą ilość uzyskamy w czerwcu, natomiast najmniej w grudniu.

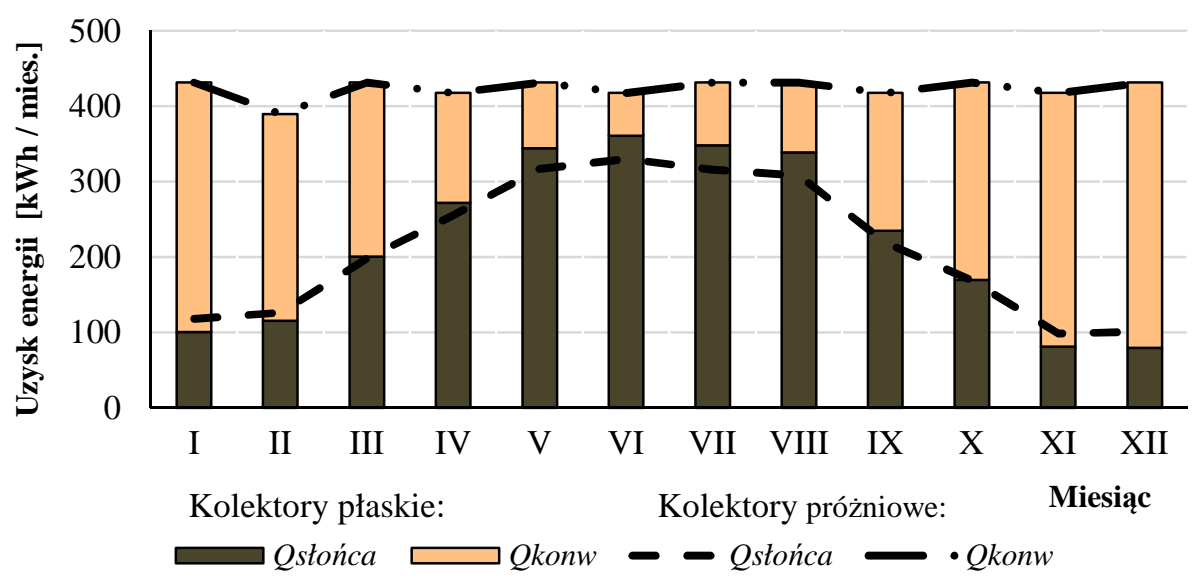

Rys. 2. Miesięczny uzysk energii z kolektorów płaskich/próżniowych oraz ze źródła konwencjonalnego

Fig. 2. Monthly energy yield by solar flat-plate/evacuated tube collectors and conventional source

Lepszy profil energii, pozyskanej w ciągu roku ze źródła konwencjonalnego, uzyskamy z kolektorów próżniowych. W grudniu ilość energii nie przekroczy $330 \mathrm{kWh}$. Dla kolektorów płaskich, wartość ta zostanie przekroczona w trzech miesiącach (listopad, grudzień i styczeń).

W okresie letnim ilość energii słonecznej pozyskana za pomocą kolektorów próżniowych w poszczególnych miesiącach nie przekroczy $330 \mathrm{kWh}$, natomiast w przypadku kolektorów płaskich zostanie przekroczona w maju, czerwcu, lipcu i sierpniu. Wskutek tego, roczna ilość energii słonecznej pozyskana z kolektorów płaskich jest o 3,4\% większa niż z kolektorów próżniowych (w sezonie letnim oraz zimowym o ok. 8,8\%). 


\section{Analiza finansowa}

Odtwarzalność promieniowania słonecznego powoduje, że po okresie zwrotu kosztów inwestycyjnych w instalację słoneczną, można uzyskać energię do wytwarzania ciepłej wody ponosząc jedynie niewielkie koszty eksploatacyjne. W trakcie eksploatacji użytkownik ponosi tylko koszty za energię pobraną przez sterownik i pompę obiegową czynnika roboczego oraz wymianę czynnika. Czynnik roboczy zaleca się wymieniać raz na 5 lat. Żywotność instalacji słonecznej jest oceniana na około 20 lat i dotyczy okresu, w którym kolektory słoneczne są w stanie efektywnie produkować ciepło. Jednak w praktyce okres ten jest o wiele dłuższy. Decyzja o wymianie paneli słonecznych jest często podyktowana tym, że na rynku z czasem pojawiają się nowe modele paneli słonecznych (o wyższej sprawności), niż fakt obniżenia sprawności absorbera.

Tabela 5. Oszczędności w wyniku wykorzystania energii słonecznej Z

Table 5. Savings a result of using solar energy $Z$

\begin{tabular}{|c|c|c|c|c|c|c|c|c|c|}
\hline \multirow{3}{*}{$\begin{array}{l}\text { Podstawowy } \\
\text { nośnik } \\
\text { energii } \\
\text { w budynku }\end{array}$} & \multirow{3}{*}{$\begin{array}{c}\text { Koszt } \\
\text { jedn. } \\
\text { energii } \\
{[\mathbf{z} / \mathbf{k W h}]}\end{array}$} & \multirow{2}{*}{\multicolumn{2}{|c|}{$\begin{array}{c}\text { Zaoszczędzona } \\
\text { energia przy } \\
\text { ekspl. rocznej } \\
\text { [kWh/rok] } \\
\end{array}$}} & \multirow{2}{*}{\multicolumn{2}{|c|}{$\begin{array}{c}\text { Zaoszczędzona } \\
\text { energia przy ekspl. } \\
\text { sezonowej (IV-IX) } \\
{[\mathrm{kWh} / \mathrm{sezon}]} \\
\end{array}$}} & \multicolumn{4}{|c|}{ Zysk Z } \\
\hline & & & & & & \multicolumn{2}{|c|}{ Rok [zt/rok] } & \multicolumn{2}{|c|}{$\begin{array}{c}\text { Sezon (IV-IX) } \\
\text { [zł/sezon] }\end{array}$} \\
\hline & & $\begin{array}{c}\text { kol. } \\
\text { płaskie }\end{array}$ & $\begin{array}{c}\text { kol. próż- } \\
\text { niowe }\end{array}$ & $\begin{array}{c}\text { kol. } \\
\text { płaskie }\end{array}$ & $\begin{array}{c}\text { kol. próż- } \\
\text { niowe }\end{array}$ & $\begin{array}{c}\text { kol. } \\
\text { płaskie }\end{array}$ & $\begin{array}{c}\text { kol. } \\
\text { próżniowe }\end{array}$ & $\begin{array}{c}\text { kol. } \\
\text { płaskie }\end{array}$ & \begin{tabular}{|c|} 
kol. \\
próżniowe
\end{tabular} \\
\hline Gaz ziemny & 0,12 & \multirow{2}{*}{2648} & \multirow{2}{*}{2561} & \multirow{2}{*}{1900} & \multirow{2}{*}{1748} & 318 & 307 & 228 & 210 \\
\hline En. elektryczna & 0,59 & & & & & 1562 & 1511 & 1121 & 1031 \\
\hline
\end{tabular}

Czas zwrotu kosztów inwestycji metodą statyczną $T_{z u}$ oblicza się jako iloraz kosztów całej inwestycji $K_{i}$ (koszty zakupu poszczególnych elementów instalacji wraz z kosztami montażu) oraz różnicy kwoty jaką zaoszczędziliśmy wykorzystując alternatywne źródło energii $Z$ oraz kosztów poniesionych na eksploatacje systemu w ciągu jednego roku $K_{e k s}[8]$.

Pompa obiegowa $(63 \mathrm{~W})$ będzie pracować ok. 9 godzin dziennie w okresie letnim oraz 4 godziny dziennie w okresie zimowym, w przypadku, kiedy instalacja będzie użytkowana cały rok. Poniesione koszty energii elektrycznej wynoszą: $K_{\text {ell }(r o k)}=88,3 \mathrm{zł} / \mathrm{rok}$, w tym $K_{\text {ell(lato })}=61,2 \mathrm{zt} / \mathrm{sezon}$.

Jednostkowy koszt ciepła wytworzonego z prądu jest wyższy od kosztu ponoszonego przy wykorzystaniu gazu ziemnego. Roczny zysk zastąpienia energii elektrycznej, jako podstawowego źródła, energią pozyskaną z kolektorów słonecznych jest ok. 5 razy wyższy w porównaniu z gazem ziemnym (tab. 5).

$\mathrm{W}$ ramach dofinansowania $\mathrm{z}$ programu PROSUMENT w $2016 \mathrm{r}$. istnieje możliwość 20\% dotacji do instalacji kolektorowej, a po 2016 r. 15\% dotacji. Możliwość skorzystania z dofinansowania jest możliwa jedynie wraz z wzięciem kredytu preferencyjnego [9]. 
Opłacalność wykorzystania energii słonecznej wystąpi przy zastąpieniu źródła ciepłej wody zasilanego energią elektryczną. Wówczas czas zwrotu kosztów bez dotacji dla kolektorów płaskich wynosi 7,5 lat, a kolektorów próżniowych jest nieco wyższy i wynosi 9,5 lat (tab. 6).

Tabela 6. Okres zwrotu kosztów instalacji słonecznej

Table 6. Payback period of the solar system

\begin{tabular}{|l|c|c|c|c|}
\hline \multirow{2}{*}{$\begin{array}{c}\text { Podstawowy } \\
\text { nośnik energii } \\
\text { w budynku }\end{array}$} & \multicolumn{2}{|c|}{$\begin{array}{c}\text { Okres zwrotu kosztów inwestycji } \\
\text { bez korzystania z dotacji, [lat] }\end{array}$} & $\begin{array}{c}\text { Okres zwrotu kosztów inwestycji } \\
\text { z 20\% dotacją, [lat] }\end{array}$ \\
\cline { 2 - 5 } & kol. płaskie & kol. próżniowe & kol. płaskie & kol. próżniowe \\
\hline Gaz ziemny & 34,5 & 44,5 & 30,5 & 39,0 \\
\hline En. elektryczna & 7,5 & 9,5 & 6,5 & 8,5 \\
\hline
\end{tabular}

W przypadku wykorzystania innych rodzajów energii konwencjonalnej okres zwrotu kosztów instalacji solarnej zdecydowanie przekracza okres przyjmowanej żywotności instalacji. Biorąc pod uwagę aspekty ekologiczne instalacja słoneczna bez wątpienia przewyższa inne konwencjonalne źródła energii dostarczające do środowiska szkodliwe zanieczyszczenia, które narastając z biegiem czasu będą miały negatywny wpływ na otoczenie, w którym żyjemy.

Korzystając z dotacji w przypadku analizowanych inwestycji można zaoszczędzić 11,4\% całkowitych kosztów inwestycji, zarówno w przypadku instalacji z kolektorami płaskimi jak i próżniowymi. Czas zwrotu kosztów inwestycji po skorzystaniu z dofinansowania skróci się w przypadku energii elektrycznej o rok, a gazu o ok. 5 lat (tab. 6).

Analiza opłacalności inwestycji z zastosowaniem metody dynamicznej z wykorzystaniem wskaźnika $N P V$ pozwoliła na wyznaczenie wartości bieżącej netto [10]. Wyznaczono przepływy pieniężne, w każdym roku użytkowania inwestycji, zakładając 20 letni okres użytkowania instalacji. Uwzględniono współczynnik dyskontujący przy założeniu stałej stopy dyskontowej, która w roku 2016 wynosi $r=2,83 \%$ [11]. Obliczenie przepływów pieniężnych wymagało uwzględnienia, w poszczególnych latach eksploatacji, nakład inwestycyjny $I N V_{t}$ [zł] oraz oszczędności wynikających z użytkowania instalacji $Z$ [zł].

W interpretacji wyników obliczeń wskaźnika $N P V$ skorzystano z założenia, że jeśli $N P V>0$, to inwestycja jest opłacalna; jeżeli $N P V=0$, to zyski wynikające $\mathrm{z}$ użytkowania instalacji równoważą się z nakładami inwestycyjnymi na tę instalację, natomiast w przypadku $N P V<0$ inwestycja jest nieopłacalna [10].

Wartość nakładów inwestycyjnych $I N V$ dla pierwszego roku inwestycji jest równa całkowitej wartości instalacji słonecznej. Dla instalacji z kolektorami płaskimi wynosi $I N V=12612 \mathrm{zł}$, natomiast dla instalacji z kolektorami próżniowymi $I N V=15804$ zł. W kolejnych latach użytkowania instalacji $I N V$ przyjmuję wartość kosztów jakie użytkownik ponosi w wyniku jej eksploatacji tj. wymiana 
czynnika roboczego oraz zużycie energii elektrycznej na pracę pompy obiegowej. Wartość $I N V$ w następnych lat eksploatacji jest stała, zarówno dla instalacji z kolektorami płaskimi jak i próżniowymi, i wynosi $I N V=137$ zł.

Zakładając, że podstawowym źródłem wytwarzania ciepłej wody jest energia elektryczna obliczona wartość $N P V$, stanowiąca sumę zdyskontowanej wartości oszczędności wynikającej z użytkowania instalacji słonecznej dla 20 lat eksploatacji, wyniosła: dla kolektorów płaskich $N P V=9676,66>0$, a dla kolektorów próżniowych $N P V=5687,37>0$. Wyniki obliczeń pokazują, że inwestycja jest opłacalna.

Gdy podstawowym źródłem wytwarzania ciepłej wody jest gaz ziemny wartość $N P V$ wyniosła: dla kolektorów płaskich $N P V=-9665,05<0$, a dla kolektorów próżniowych $N P V=-13020,24>0$. Świadczy to o nieopłacalności inwestycji.

\section{Podsumowanie}

Rozwiązywanie zagadnienia efektywności energetycznej wykorzystania energii słonecznej w ogrzewaniu ciepłej wody przeprowadza się na podstawie analizy energetyczno-ekonomicznej opisanej przez wskaźniki techniczne i finansowe. W metodzie f-czart wyznaczone wskaźniki techniczne $X$ i $Y$ i funkcja korelacyjna $f$ pozwalają na obliczanie energii pozyskanej ze Słońca oraz źródła konwencjonalnego $\mathrm{w}$ kolejnych miesiącach roku, w określonych przedziałach czasu (sezon) oraz w ciągu całego roku.

Analiza instalacji wykazała, że w sezonie letnim (IV-IX) możliwe jest większe o 8,7\% pozyskanie energii słonecznej przez kolektory cieczowe płaskie w porównaniu z kolektorami próżniowymi (rocznie o 3,4\%). Natomiast kolektory próżniowe charakteryzuje korzystniejszy w okresie zimy profil energii pozyskanej ze źródła konwencjonalnego, z uwagi na wyższą o 5\% sprawność instalacji z kolektorami próżniowymi, w porównaniu z kolektorami płaskimi.

$\mathrm{Z}$ przeprowadzonej na podstawie wskaźników finansowych analizy wynika, że najbardziej opłacalna jest rozwiązanie, kiedy w celu ogrzewania wody energia słoneczna będzie zastępowała źródło ciepła wykorzystujące energię elektryczną. W analizowanych instalacjach czas zwrotu kosztów inwestycyjnych wynosi 7,5 lat dla instalacji z kolektorami płaskimi i 9,5 lat dla instalacji z kolektorami próżniowymi. W przypadku wspomagania instalacji źródłem opartym o gaz ziemny czas zwrotu kosztów inwestycyjnych instalacji słonecznej wielokrotnie przewyższa zakładany czas eksploatacji kolektorów słonecznych, i w związku z tym to rozwiązanie jest nieopłacalne.

Metoda f-chart zastosowana w obliczeniach pozwala na ocenę efektów działania instalacji słonecznej na podstawie podstawowej charakterystyki kolektorów i uśrednionych miesięcznych danych meteorologicznych. Skutkiem tego jest bardzo użyteczna w wykonywaniu badań i opracowań z zakresu ocen energetycznych, które służą poszukiwaniu optymalnych rozwiązań instalacji słonecznych. 


\section{Literatura}

[1] E. Rybak-Wilusz, V. Pisarev, P. Sawicka "Urządzenia zintegrowanych systemów zaopatrzenia w energie budynku zamieszkania zbiorowego". Czasopismo Inżynierii Lądowej, Środowiska i Architektury - Journal of Civil Engineering, Environment and Architecture JCEEA, t. XXXI, z. 61 (3/II/14), lipiec-wrzesień 2014, s. 459-468, DOI:10.7862/rb.2014.112.

[2] I. F. Okafor and G. Akubue "F-Chart Method for Designing Solar Thermal Water Heating Systems", International Journal of Scientific \& Engineering Research, Vol. 3, Issue 9, September - 2012.

[3] Wolańczyk F. „Jak wykorzystać darowaną energię” KaBe, Krosno 2011.

[4] K. Sujith "Design Of Active Solar Water Heating System Using F-Chart Method", International Journal of Engineering Research \& Technology, Vol. 2 Issue 7, July 2013.

[5] Pluta Z. „Słoneczne instalacje energetyczne” Oficyna Wydawnicza Politechniki Warszawskiej, Warszawa 2007.

[6] „Sprawozdanie z przeprowadzonych badań i wykonania charakterystyk cieplnych kolektora promieniowania słonecznego HELIOSTAR 202 firmy THERMO SOLAR POLSKA", Instytut Podstawowych Problemów Techniki Polskiej Akademii Nauk, Warszawa 2011.

[7] Solar water heating project analysis - RETscreen International Clean Energy Project Analysis Course, Minister of Natural Sources Canada 2001-2014.

[8] Dąbrowski J. „Kolektory słoneczne do podgrzewania wody użytkowej. Efektywność i opłacalność instalacji” Wydawnictwo Uniwersytetu Przyrodniczego we Wrocławiu, Wrocław 2009.

[9] www.nfosigw.gov.pl - strona internetowa Narodowego Funduszu Ochrony Środowiska i Gospodarki Wodnej, (dostęp 4.04.2016).

[10] J. Górzyński "Audyting energetyczny obiektów przemysłowych" Fundacja Poszanowania Energii, Warszawa 1995.

[11] www.uokik.gov.pl - strona internetowa Urzędu Ochrony Konsumentów i Konkurencji, (dostęp 28.04.2016).

[12] http://mib.gov.pl/2 Wskazniki_emisji_wartosci_opalowe_paliwa.html - dane meteorologiczne do obliczeń energetycznych budynków Ministerstwa Infrastruktury i Budownictwa, (dostęp 4.03.2016).

[13] www.pogodynka.pl/polska/daneklimatyczne/ - serwis pogodowy IMGW - średnie temperatury powietrza dla poszczególnych miesięcy w Polsce, (dostęp 3.01.2016).

\section{ENERGY AND ECONOMIC ANALYSIS OF SOLAR ENERGY UTILIZATION}

\section{S u m m a r y}

The purpose of this analysis is to evaluation of the efficiency of utilization solar energy to heat hot water in the solar thermal collectors installation. It involves, among other things, determining the energy volume of solar irradiation reaching to the solar collector surface 
and identify heat demand. In the longer periods of time (month, year) the heat consumption for heating hot water is constants, in contrary to changes of solar irradiance. This causes some difficulty in estimating the effects of the solar installation. The position of the Sun determines the number of parameters used to calculate the components solar radiation. In the study was made an energy evaluation of the solar installation in residential building using the method f-chart. It is based on a general characteristics of solar collectors and an averaged meteorological data. Comparative analysis of two installations with flat-plate solar collectors and evacuated tube collector has been made. Economic analysis of the solar system provides a complete picture of savings from utilization solar energy and indicates a solution, taking into account investment and operating costs. Conclusions of this analysis indicate the factors which may be taken into account when choosing the type of solar collectors and practical design solutions, solar installations with high thermal efficiency.

Keywords: f-chart method, liquid flat-plate solar collector, evacuated tube collector, hot water installation, energy efficiency, economic indicators

DOI:10.7862/rb.2016.291

Przestano do redakcji: $30.06 .2016 r$.

Przyjęto do druku: 20.12.2016 r. 